\title{
Select bibliography
}

\section{Manuscript sources}

British Library

Additional MS 34307

Harley MS 38

Harley MS 541

Sloane MS 1423

Drapers' Company Archive, London

DB1 'Dinner Book', 1564-1602

Goldsmiths' Hall Archive, London

WA/CM [Wardens Accounts and Court Minutes], C-T (1509-1639)

C II.2.1 H. Gamon, The Gouldesmythes' Storehowse. Wherein is layde up many hidden secrets of that Ingenious Misterie (1604).

2524 The Book of Ordinances and Statutes, 1478.

\section{Guildhall Library, City of London}

Armourers' and Brasiers' Company

12071/1 Court Minutes, 1413-1559

12071/2 Court Minutes, 1559-1621

12073 Yeomanry Court Minutes, 1552-1604

12085 Livery Quarterage Book, 1604-65

12065/1 Wardens' Accounts, 1497-1563

12065/2 Wardens' Accounts, 1563-1616

12065/3 Wardens' Accounts, 1616-63

12079/2 Yeomanry Quarterly Supper Expenses Accounts, 1604-16 


$\begin{array}{ll}12157 & \text { List of armourers working at Gre } \\ 12105 & \text { Benefactions book, 1660-1877 } \\ 12106 & \text { Extracts from wills (1551-1826), } \\ 12104 & \text { Plans and Surveys of Hall and Est } \\ 12107 & \text { Inventories, 1663-1791 } \\ & \\ \text { Bakers' Company } \\ 5177 / 1 & \text { Court Minutes, 1537-61 } \\ 5177 / 2 & \text { Court Minutes, 1561-92 } \\ 5174 / 3 & \text { Wardens' Accounts, 1586-1625 } \\ 5201 & \text { Inventories, 1604-26 } \\ & \\ \text { Blacksmiths' Company } \\ 2883 / 1 & \text { Memorandum book } \\ & \\ \text { Carpenters' } & \text { Company } \\ 4329 / 1 & \text { Court Minutes, 1533-73 } \\ 4329 / 2 & \text { Court Minutes, 1573-94 } \\ 4329 / 3 & \text { Court Minutes, 1600-18 } \\ 4326 / 2 & \text { Wardens' Accounts, 1546-73 } \\ 4326 / 5 & \text { Wardens'Accounts, 1593-1613 } \\ 4326 / 6 & \text { Wardens' Accounts, 1592-1622 } \\ 4329 A & \text { Inventories, 1627-59 } \\ 4332 & \text { Register of Leases, 1477-1835 } \\ & \end{array}$

Clockmakers' Company

2710/1 Court Minutes, 1632-80

2710/2 Court Minutes, 1680/1-99

\section{Cooks' Company}

MS 3115 Benefaction Book, 1617

MS 9999 Inventories, 1752-68

Coopers' Company

5618/1 Benefactors Lists, 1718-85

5618/2 Benefactors Lists, 1718-85

5621 Inventories, 1673-1726

Cordwainers' Company

7351/1 Wardens' Accounts, 1595-1636

Curriers' Company

14357 Hall Inventory (fragment), 1558 
Cutlers' Company

$7164 \quad$ Inventories, 1586-1664

Founders' Company

$6335 \quad$ Court Orders, 1603-38

6330/1 Wardens' Accounts, 1497-1576

6330/2 Wardens' Accounts, 1576-1681

6353/1 'Some Account of the Worshipful Company of Founders', 1800? -1867?

6353/2 'Some Account of the Worshipful Company of Founders', 1800? -1867?

Girdlers' Company

5817 Benefactions Book, 1431-1638

Haberdashers' Company

15868 Yeomanry Wardens' Accounts, 1601-61

15874 'The State of the Charities, 1597'

Ironmongers' Company

16967/1 Court Minutes, 1555-1603

16988/2 Wardens' Accounts, 1539-92

16988/3 Wardens' Accounts, 1593-1616

16988/4 Wardens' Accounts, 1616-34

16988/5 Wardens' Accounts, 1634-51

16960 Will Book, 1471-1799

17155 Surveyor's Reports and Plans, 1613-14

Parish Clerks' Company

$4890 \quad$ Receipt Book, 1583-1657

Pewterers' Company

7090/1 Court Minutes, 1551-61

7090/2 Court Minutes, 1561-89

7090/3 Court Minutes, 1589-1611

7090/4 Court Minutes, 1611-43

22181 Yeomanry Wardens' Accounts, 1608-19

22191 Wardens' Accounts - expenditure on dinners, 1637-53

7110 Inventories, 1490-1756

Plumbers' Company

MS 2208/1 Court Minutes, 1621-47

Tallow Chandlers' Company

6152/1 Court Minutes, 1534-77

6153/1 Court Minutes, 1607-48 
6163/1 Papers concerning entertainments and ceremonies, 1624-39, 1662-75

6155/1 Yeomanry Wardens' Accounts, 1519-49

6155/2 Yeomanry Wardens' Accounts, 1550-1627

Tylers' and Bricklayers' Company

3043/1 Court Minutes, 1580-1667

Weavers' Company

4646 Wardens' Accounts, 1588-1732

\section{London Metropolitan Archive}

LMA, COL/CA/01/01/030 Repertory of the Court of Aldermen, 1605-7

LMA, COL/CA/01/01/033 Repertory of the Court of Aldermen, 1610-12

LMA, COL/CA/01/01/038 Repertory of the Court of Aldermen, 1618-20

LMA, COL/CA/01/01/039 Repertory of the Court of Aldermen, 1620-21

COL/SJ/27/465 Viewers' Reports, 1623-36

\section{The National Archive, Kew}

Probate Records:

PROB 11/46/67

PROB 11/53/33

PROB 11/203/300

PROB 11/61/343

PROB 11/132/202

PROB 11/192/524

\section{Sir John Soane's Museum, London}

MS 22 The Account Book of Nicholas Stone

MS 23 The Note Book of Nicholas Stone

\section{Published sources}

\section{Primary sources}

Agricola, Georgius, De Re Metallica, trans. by Herbert Hoover and Lou Hoover (New York, 1950).

The Annals of the Barber-Surgeons of London, compiled from their records and other sources, by Sidney Young (London: Blades, East \& Blades, 1890).

B., W., A touch-stone for gold and silver wares; or, a manual for goldsmiths and all other persons, whether buyers, sellers, or wearers of any manner of goldsmiths work (London, 1677).

Bacon, Francis, Novum Organum: with other parts of the great instauration, trans. and ed. by Peter Urbach and John Gibson (Chicago, IL: Open Court, 1994).

Calendar of Wills Proved and Enrolled in the Court of Husting, London, A.D. 1258-A.D. 1688, ed. by Reginald R. Sharpe, 2 vols (London: John C. Francis, 1889-90). 
The Diary of Samuel Pepys: A Selection. Selected and ed. by Robert Latham from The Diary of Samuel Pepys, a New and Complete Transcription, ed. by Robert Latham and Matthew Williams (London: Penguin Books, 2003).

The De Moneta of Nicolas Oresme and English Mint Documents, trans. by C. Johnson (London; New York: Nelson 1956).

Dee, John, The Mathematicall Preface to the Elements of Geometrie of Euclid of Megara (London, 1570).

Digges, Leonard, A boke named tectonicon briefelye shewynge the exacte measurynge, and speady rekenynge all maner lande, squared timber, stone, steaples, pyllers, globes (London, 1556).

The Dinner Book of the London Drapers' Company, 1564-1602, ed. by Sarah Milne (Woodbridge: The Boydell Press, 2019).

Ercker, Lazarus, Treatise on Ores and Assaying, trans. by Anneliese Grünhaldt Sisco and Cyril Stanley Smith (Chicago, IL: University of Chicago Press, 1951).

Gerhold, Dorian, London Plotted: Plans of London Buildings c. 1450-1720 (London: London Topographical Society, 2016).

Harrison, William, The description of England, ed. by George Edelen (Washington, DC: Folger Shakespeare Library, and Dover; London: Constable, 1994).

The London Surveys of Ralph Treswell, ed. by John Schofield (London: London Topographical Society, 1987).

London Viewers and their Certificates, 1508-1558: Certificates of the Sworn Viewers of the City of London, ed. by Janet Senderowitz Loengard (London: London Record Society, 1989).

Machyn, Henry, The Diary of Henry Machyn, Citizen and Merchant-Taylor of London, from A.D. 1550 to A.D. 1563, ed. by John Gough (London, 1848).

Memorials of the Guild of Merchant Taylors of the Fraternity of St. John the Baptist, in the City of London; and of its Associated Charities and Institutions, compiled and selected by Charles M. Clode (London: Harrison \& Sons, 1875).

Milles, Thomas, The custumers alphabet and primer (London, 1608).

Monconys, Balthasar de, Journal des Voyages, 2 vols (Lyon, 1665-66).

More, Richard, The carpenters rule; or, a book shewing many plain waies, truly to measure ordinarie timber (London, 1602).

Moxon, Joseph, Mechanick exercises: or, the doctrine of handy-works (London, 1677). Munday, Anthony, Chruso-Thriambos: The Triumphes of Golde (London, 1611).

The Notebooks of Nehemiah Wallington, 1618-1654, ed. by David Booy (Aldershot: Ashgate, 2007).

Prideaux, Walter Sherburne, Memorials of the Goldsmiths' Company, 2 vols (London: Eyre and Spottiswoode, 1896-97).

Records of the Worshipful Company of Carpenters, ed. by B. Marsh, J. Ainsworth, and A. M. Millard, 7 vols (Oxford: Oxford University Press, 1914-68).

Records of the Worshipful Company of Tallow Chandlers, ed. by M. F. Monier-Williams, 2 vols (London, 1897-98).

Spiers, Walter Lewis, 'The note-book and account book of Nicholas Stone', The Volume of the Walpole Society, 7 (1918-19), pp. 1-200.

Stuart Royal Proclamations, ed. by James F. Larkin and Paul L. Hughes, 2 vols (Oxford: Clarendon Press, 1973-).

A Survey of Documentary Sources for Property Holding before the Great Fire, ed. by Derek Keene and Vanessa Harding (London, 1985), British History Online, www.british-history.ac.uk/london-record-soc/vol22 [accessed 14 July 2020]. 
A Survey of London by John Stow; Reprinted from the Text of 1603, with Introduction and Notes by Charles Lethbridge Kingsford, 2 vols (Oxford: Clarendon Press, 1908).

Wardens' Accounts of the Worshipful Company of Founders of the City of London, 1497-1681. Transcribed, calendared, and edited by Guy Parsloe (London: Athlone Press, 1964).

Wotton, Henry, The Elements of Architecture, collected by Henry Wotton Knight, from the Best Authors and Examples (London, 1624).

\section{Secondary sources}

Alford, B. and Barker, T. C., A History of the Carpenters' Company (London: Allen and Unwin, 1968).

Amelang, James S., The Flight of Icarus: Artisan Autobiography in Early Modern Europe (Stanford, CA: Stanford University Press, 1998).

Anderson, Christy, Inigo Jones and the Classical Tradition (Cambridge: Cambridge University Press, 2007).

Anderson, Christy, 'Live words and experience in early modern architecture', in Nebahat Avcioglu and Allison Sherman (eds), Artistic Practices and Cultural Transfer in Early Modern Italy: Essays in Honour of Deborah Howard (Farnham: Ashgate, 2015), pp. 77-87.

Appadurai, Arjun, 'Introduction: commodities and the politics of value', in Appadurai (ed.), The Social Life of Things: Commodities in Cultural Perspective (Cambridge: Cambridge University Press, 1986), pp. 3-63.

Archer, Ian, The Pursuit of Stability: Social Relations in Elizabethan London (Cambridge: Cambridge University Press, 1991).

Archer, Ian, 'The arts and acts of memorialisation in early modern London', in J. F. Merritt (ed.), Imagining Early Modern London: Perceptions and Portrayals of the City from Stow to Strype, 1598-1720 (Cambridge: Cambridge University Press, 2001), pp. 89-113.

Archer, Ian, 'The livery companies and charity in the sixteenth and seventeenth centuries', in Ian Anders Gadd and Patrick Wallis (eds), Guilds, Society and Economy in London 1450-1800 (London: Centre for Metropolitan History, Institute of Historical Research in association with Guildhall Library, 2002), pp. 15-28.

Archer, Ian, 'Discourses of history in Elizabethan and early Stuart London', Huntingdon Library Quarterly, 68: 1-2 (2005), 205-26.

Archer, Jayne E., Goldring, Elizabeth, and Knight, Sarah (eds), The Intellectual and Cultural World of the Early Modern Inns of Court (Manchester; New York: Manchester University Press, 2011).

Arnade, Peter, Howell, Martha, and Simons, Walter, 'Fertile spaces: the productivity of urban space in northern Europe', The Journal of Interdisciplinary History, 32:4 (2002), 515-48.

Ash, Eric, Power, Knowledge and Expertise in Elizabethan England (Baltimore, MD; London: Johns Hopkins University Press, 2004).

Ash, Eric (ed.), Expertise: Practical Knowledge and the Early Modern State (Chicago, IL: University of Chicago Press, 2010).

Ashton, Robert, The City and the Court, 1603-1643 (Cambridge: Cambridge University Press, 1979).

Barron, Caroline, London in the Later Middle Ages: Government and People, 1200-1500

(Oxford: Oxford University Press, 2004). 
Barry, Jonathan, 'Bourgeois collectivism? Urban association and the middling sort', in Jonathan Barry and Christopher Brooks (eds), The Middling Sort of People: Culture, Society and Politics in England, 1550-1800 (London: Macmillan, 1994), pp. 84-112.

Ben-Amos, Ilana Krausman, The Culture of Giving: Informal Support and GiftExchange in Early Modern England (Cambridge: Cambridge University Press, 2008).

Bergeron, David M., English Civic Pageantry, 1558-1642, rev. edn (Tempe, AZ: Arizona State University, 2003).

Berlin, Michael, 'Civic ceremony in early modern London', Urban History Yearbook, 13 (1986), 15-27.

Berlin, Michael, "'Broken all in pieces”: artisans and the regulation of workmanship in early modern London', in Geoffrey Crossick (ed.), The Artisan and the European Town, 1500-1900 (Aldershot: Scolar, 1997), pp. 75-91.

Berlin, Michael, 'Guilds in decline? London livery companies and the rise of a liberal economy, 1600-1800', in S. R. Epstein and Maarten Prak (eds), Guilds, Innovation and the European Economy, 1400-1800 (Cambridge: Cambridge University Press, 2008), pp. 316-41.

Bertucci, Paola, Artisanal Enlightenment: Science and the Mechanical Arts in Old Regime France (New Haven, CT: Yale University Press, 2017).

Bishop, Jennifer, 'The clerk's tale: civic writing in sixteenth-century London', in Liesbeth Corens, Kate Peters, and Alexandra Walsham (eds), The Social History of the Archive: Record Keeping in Early Modern Europe, Past and Present Supplement 11 (Oxford, 2016), pp. 112-30.

Branch, Laura, Faith and Fraternity: London Livery Companies and the Reformation, 1510-1603 (Leiden; Boston, MA: Brill, 2017).

Brigden, Susan, 'Religion and social obligation in early sixteenth-century London', Past and Present, 103:1 (1984), 67-112.

Capp, Bernard, The World of John Taylor the Water-Poet (Oxford: Clarendon, 1994).

Cavallo, Sandra, Artisans of the Body in Early Modern Italy (Manchester: Manchester University Press, 2007).

Cooper, Nicholas, Houses of the Gentry: 1480-1680 (New Haven, CT; London: Yale University Press, 1999).

Cooper, Nicholas, 'Rank, manners and display: the gentlemanly house, 1500-1750', Transactions of the Royal Historical Society, 12 (2002), 291-310.

Cooper, Tarnya, Citizen Portrait: Portrait Painting and the Urban Elites of Tudor and Jacobean England and Wales (New Haven, CT; London: Yale University Press, 2012).

Cressy, David, Literacy and the Social Order: Reading and Writing in Tudor and Stuart England (Cambridge: Cambridge University Press, 1980).

Davids, Karel, 'Craft secrecy in Europe in the early modern period: a comparative view', Early Science and Medicine, 10:3 (2005), 341-8.

Davis, Natalie Zemon, The Gift in Sixteenth-Century France (Oxford: Oxford University Press, 2000).

Dillon, Janette, The Language of Space in Court Performance, 1400-1625 (Cambridge: Cambridge University Press, 2010).

Durning, Louise, 'The Oxford college as household, 1580-1640', in Sandra Cavallo and Silvia Evangelisti (eds), Domestic Institutional Interiors in Early Modern Europe (Farnham: Ashgate, 2009), pp. 83-101. 
Eamon, William, Science and the Secrets of Nature: Books of Secrets in Medieval and Early Modern Culture (Princeton, NJ: Princeton University Press, 1994).

Eamon, William, 'How to read a book of secrets', in Elaine Leong and Alisha Rankin (eds), Secrets and Knowledge in Medicine and Science, 1500-1800 (Burlington, VT: Ashgate, 2011), pp. 23-46.

Epstein, S. R., 'Craft guilds, apprenticeship and technological change in pre-industrial Europe', The Journal of Economic History, 58:3 (1998), 684-713.

Erickson, Amy, 'Eleanor Mosley and other milliners in the City of London companies 1700-1750', HWJ, 71:1 (2011), 147-72.

Farr, James R., Hands of Honor: Artisans and Their World in Dijon, 1550-1650 (Ithaca, NY; London: Cornell University Press, 1988).

Farr, James R., 'On the shop floor: guilds, artisans and the European market economy, 1350-1750', Journal of Early Modern History, 1:1 (1997), 24-54.

Farr, James R., Artisans in Europe, 1300-1914 (Cambridge: Cambridge University Press, 2000).

Flather, Amanda, Gender and Space in Early Modern England (Woodbridge: Boydell, 2007).

Fox, Adam, Oral and Literate Culture in England 1500-1700 (Oxford: Clarendon, 2000).

Friedrich, Markus, The Birth of the Archive: A History of Knowledge in the Early Modern World, trans. by John Noël Dillon (Ann Arbor: University of Michigan Press, 2018).

Gadd, Ian Anders and Wallis, Patrick (eds), Guilds, Society and Economy in London 1450-1800 (London: Centre for Metropolitan History, Institute of Historical Research in association with Guildhall Library, 2002).

Girouard, Mark, Elizabethan Architecture: Its Rise and Fall, 1540-1640 (New Haven, CT: Yale University Press, 2009).

Gerbino, Anthony and Johnston, Stephen, Compass and Rule: Architecture as Mathematical Practice in England, 1500-1750 (New Haven, CT; London: Yale University Press, 2009).

Giles, Katherine, "The "familiar" fraternity: the appropriation and consumption of medieval guildhalls in early modern York', in Sarah Tarlow and Susie West (eds), The Familiar Past? Archaeologies of Later Historical Britain (London; New York, Routledge, 1999), pp. 87-102.

Giles, Katherine, An Archaeology of Social Identity: Guildhalls in York, c.1350-1630 (Oxford: J. and E. Hedges, 2000).

Gordon, Andrew, Writing Early Modern London: Memory, Text and Community (New York: Palgrave Macmillan, 2013).

Gowing, Laura, “'The freedom of the streets”: women and social space, 1560-1640', in Paul Griffiths and Mark Jenner (eds), Londinopolis: Essays in the Social and Cultural History of Early Modern London (Manchester: Manchester University Press, 2000), pp. 130-51.

Gowing, Laura, 'Girls on forms: apprenticing young women in seventeenth-century London', Journal of British Studies, 55:3 (2016), 447-73.

Grassby, Richard, 'Material culture and cultural history', The Journal of Interdisciplinary History, 35:4 (2005), 591-603.

Griffiths, Paul, 'Secrecy and authority in late sixteenth- and seventeenth-century London’, The Historical Journal, 40 (1997), 925-51. 
Griffiths, Paul, 'Politics made visible: order, residence and uniformity in Cheapside, 1558-1645', in Paul Griffiths and Mark Jenner (eds), Londinopolis: Essays in the Social and Cultural History of Early Modern London (Manchester: Manchester University Press, 2000), pp. 176-96.

Hamling, Tara and Richardson, Catherine, A Day at Home in Early Modern England: Material Culture and Domestic Life, 1500-1700 (New Haven, CT: Yale University Press, 2017).

Hanawalt, Barbara A., Ceremony and Civility: Civic Culture in Late Medieval London (New York: Oxford University Press, 2017).

Harding, Vanessa, 'The population of London, 1550-1700: a review of the published evidence', The London Journal, 15:2 (1990), 111-28.

Harding, Vanessa, 'Space, property, and propriety in urban England', The Journal of Interdisciplinary History, 32: 4 (2002), 549-69.

Harding, Vanessa, 'Cheapside: commerce and commemoration', Huntingdon Library Quarterly, 71:1 (2008), 77-96.

Harkness, Deborah E., The Jewel House: Elizabethan London and the Scientific Revolution (New Haven, CT; London: Yale University Press, 2007).

Harris, Eileen, British Architectural Books and Writers 1556-1785 (Cambridge: Cambridge University Press, 1990).

Heal, Felicity, Hospitality in Early Modern England (Oxford: Clarendon Press, 1990).

Heal, Felicity, The Power of Gifts: Gift-Exchange in Early Modern England (Oxford: Oxford University Press, 2014).

Herbert, William, The History of the Great Twelve Livery Companies of London, 2 vols (London, 1837).

Hill, Tracey, Pageantry and Power: A Cultural History of the Early Modern Lord Mayor's Show, 1585-1639 (Manchester: Manchester University Press, 2010).

Hills, Helen, 'Theorizing the relationship between architecture and gender in early modern Europe', in H. Hills (ed.), Architecture and the Politics of Gender in Early Modern Europe (Aldershot: Ashgate, 2003), pp. 3-22.

Howard, Maurice, 'Classicism and civic architecture in Renaissance England', in Lucy Gent (ed.), Albion's Classicism: The Visual Arts in Britain, 1550-1660 (New Haven, CT; London: Yale University Press, 1995), pp. 29-49.

Hubbard, Eleanor, City Women: Money, Sex, and the Social Order in Early Modern London (Oxford: Oxford University Press, 2012).

Jacobi, Lauren, The Architecture of Banking in Renaissance Italy: Constructing the Spaces of Money (Cambridge: Cambridge University Press, 2019).

Johnson, Matthew, 'Meanings of polite architecture in sixteenth-century England', Historical Archaeology, 26:3 (1992), 45-56.

Johnson, Matthew, Housing Culture: Traditional Architecture in an English Landscape (London: UCL Press, 1993).

Johnson, Matthew, English Houses, 1300-1800: Vernacular Architecture, Social Life (Harlow: Longman, 2010).

Johnston, Stephen, 'Mathematical practitioners and instruments in Elizabethan England', Annals of Science, 48:4 (1991), 319-44.

Jupp, Edward Basil, An Historical Account of the Worshipful Company of Carpenters of the City of London: Chiefly Compiled from Records in their Possession (London: W. Pickering, 1848).

Jütte, Daniel, The Age of Secrecy: Jews, Christians, and the Economy of Secrets, 1400-1800, trans. by Jeremiah Riemer (New Haven, CT: Yale University Press, 2015). 
Jütte, Daniel, The Strait Gate: Thresholds and Power in Western History (New Haven, CT: Yale University Press, 2015).

Karras, Ruth Mazo, From Boys to Men: Formations of Masculinity in Late Medieval Europe (Philadelphia, PA: University of Pennsylvania Press, 2003).

Kilburn-Toppin, Jasmine, 'Gifting cultures and artisanal guilds in sixteenth- and early seventeenth-century London’, The Historical Journal, 60:4 (2017), 865-87.

Kilburn-Toppin, Jasmine, "'A place of great trust to be supplied by men of skill and integrity": assayers and knowledge cultures in late sixteenth- and seventeenthcentury London', The British Journal for the History of Science, 52:2 (2019), 197-223.

King, Chris, 'The interpretation of urban buildings: power, memory and appropriation in Norwich merchants' houses, c. 1400-1660', World Archaeology, 41:3 (2009), 471-88.

Laitinen, Riitta and Cohen, Thomas V. (eds), Cultural History of Early Modern Streets (Leiden; Boston, MA: Brill, 2009).

Lancashire, Anne, London Civic Theatre: City Drama and Pageantry from Roman times to 1558 (Cambridge: Cambridge University Press, 2002).

Lefebvre, Henri, The Production of Space, trans. by Donald Nicholson-Smith (Oxford: Blackwell Publishing, 1991).

Long, Pamela O., 'The openness of knowledge: an ideal and its context in sixteenthcentury writings on mining and metallurgy', Technology and Culture, 32:2 (1991), 318-55.

Long, Pamela O., Openness, Secrecy, Authorship: Technical Arts and the Culture of Knowledge from Antiquity to the Renaissance (Baltimore, MD: Johns Hopkins University Press, 2001).

Long, Pamela O., Artisan/Practitioners and the Rise of the New Sciences, 1400-1600 (Corvallis, OR: Oregon State University Press, 2011).

Luu, Lien Bich, Immigrants and the Industries of London (Aldershot; Burlington, VT: Ashgate, 2005).

Mann, Emily, 'In defence of the City: the gates of London and Temple Bar in the seventeenth century', Architectural History, 49 (2006), 75-99.

Marsh, Christopher, 'Order and place in England, 1580-1640: the view from the pew', Journal of British Studies, 44:1 (2005), 3-26.

Martin, John Jeffries, Myths of Renaissance Individualism (Basingstoke: Palgrave Macmillan, 2004).

Mauss, Marcel, The Gift: The Form and Reason for Exchange in Archaic Societies, trans. by W. D. Halls (London: Routledge, 1990).

Mitchell, David (ed.), Goldsmiths, Silversmiths and Bankers: Innovation and the Transfer of Skill, 1550 to 1750 (Stroud: A. Sutton, 1995).

Mitchell, David, Silversmiths in Elizabethan and Stuart London: Their Lives and their Marks (Woodbridge: The Boydell Press, 2017).

Mukerji, Chandra, Impossible Engineering: Technology and Territoriality on the Canal du Midi (Princeton, NJ; Oxford: Princeton University Press, 2009).

De Munck, Bert, 'Artisans, products and gifts: rethinking the history of material culture in early modern Europe', Past and Present, 224:1 (2014), 39-74.

De Munck, Burt, Kaplan, Steven L., and Soly, Hugo (eds), Learning on the Shop Floor: Historical Perspectives on Apprenticeship (New York; Oxford: Berghahn Books, 2007).

Nevola, Fabrizio, 'Street life in early modern Europe', Renaissance Quarterly, 66:4 (2013), 1332-45. 
Newman, John, 'Nicholas Stone's Goldsmiths' Hall: design and practice in the 1630s', Architectural History, 14 (1971), 30-9.

Newman, John, 'Inigo Jones and the politics of architecture', in Kevin Sharpe and Peter Lake (eds), Culture and Politics in Early Stuart England (Stanford, CA: Stanford University Press, 1993), pp. 229-56.

Ogilvie, Sheilagh, The European Guilds: An Economic Analysis (Princeton, NJ: Princeton University Press, 2019).

Orlin, Lena Cowen (ed.), Material London, ca. 1600 (Philadelphia, PA: University of Pennsylvania Press, 2000).

Orlin, Lena Cowen, Locating Privacy in Tudor London (Oxford: Oxford University Press, 2007).

Overton, Mark, et al., Production and Consumption in English Households, 1600-1750 (London: Routledge, 2004).

Pappano, Margaret A. and Rice, Nicole R., 'Medieval and early modern artisan culture', The Journal of Medieval and Early Modern Studies, 43:3 (2013), 473-85.

Peck, Linda Levy, Consuming Splendor: Society and Culture in Seventeenth-Century England (Cambridge: Cambridge University Press, 2005).

Pollmann, Judith, Memory in Early Modern Europe, 1500-1800 (Oxford: Oxford University Press, 2017).

Prak, Maarten and Wallis, Patrick (eds), Apprenticeship in Early Modern Europe (Cambridge: Cambridge University Press, 2020).

Rappaport, Steve, Worlds within Worlds: Structures of Life in Sixteenth-Century London (Cambridge: Cambridge University Press, 1989).

Reddaway, Thomas F., The Rebuilding of London after the Great Fire (London: Arnold, 1951).

Reddaway, Thomas F., 'Elizabethan London - Goldsmiths' Row in Cheapside, 1558-1645', Guildhall Miscellany, 2 (1963), 181-206.

Reddaway, Thomas and Walker, Lorna, The Early History of the Goldsmiths' Company, 1327-1509 (London: Arnold, 1975).

Rice, Nicole R. and Pappano, Margaret A., The Civic Cycles: Artisan Drama and Identity in Premodern England (Notre Dame, IN: University of Notre Dame Press, 2015).

Rosser, Gervase, 'Going to the fraternity feast: commensality and social relations in late medieval England', Journal of British Studies, 33:4 (1994), 430-46.

Rosser, Gervase, 'Crafts, guilds and the negotiation of work in the medieval town', Past and Present, 154:1 (1997), 3-31.

Rosser, Gervase, The Art of Solidarity in the Middle Ages: Guilds in England 1250-1550 (Oxford: Oxford University Press, 2015).

Schofield, John, Medieval London Houses (New Haven, CT; London: Yale University Press for the Paul Mellon Centre for Studies in British Art, 1995).

Schofield, John, The Building of London: From the Conquest to the Great Fire, 3rd rev. edn (Stroud: Sutton, 1999).

Seaver, Paul S., Wallington's World: A Puritan Artisan in Seventeenth-Century London (Stanford, CA: Stanford University Press, 1985).

Selwood, Jacob, Diversity and Difference in Early Modern London (Farnham: Ashgate, 2010).

Shapin, Steven, A Social History of Truth: Civility and Science in Seventeenth-Century England (Chicago, IL: University of Chicago Press, 1994).

Shepard, Alexandra, Meanings of Manhood in Early Modern England (Cambridge: Cambridge University Press, 2003). 
Shepard, Alexandra, Accounting for Oneself: Worth, Status, and the Social Order in Early Modern England (Oxford: Oxford University Press, 2015).

Shepard, Alexandra and Withington, Phil (eds), Communities in Early Modern England (Manchester: Manchester University Press, 2000).

Smith, Pamela H., The Body of the Artisan: Art and Experience in the Scientific Revolution (Chicago, IL: Chicago University Press, 2004).

Smith, Pamela H., 'Making and knowing in a sixteenth-century goldsmith's workshop', in L. Roberts, S. Shaffer, and P. Dear (eds), The Mindful Hand: Inquiry and Invention from the Late Renaissance to Early Industrialisation (Amsterdam: Koninkliijke Nederlandse Akademie van Wetenschappen, 2007), pp. 33-57.

Smith, Pamela H., 'Why write a book? From lived experience to the written word in early modern Europe', West 86th: A Journal of Decorative Arts, Design History, and Material Culture, 19 (2012), 25-50.

Smith, Pamela H. and Schmidt, Benjamin (eds), Making Knowledge in Early Modern Europe: Practices, Objects, and Texts, 1400-1800 (Chicago, IL; London: University of Chicago Press, 2007).

Smyth, Adam, Autobiography in Early Modern England (Cambridge: Cambridge University Press, 2010).

Spaeth, Donald, “'Orderly made”: re-appraising household inventories in seventeenthcentury England', Social History, 41:4 (2016), 417-35.

Spufford, Margaret, 'The limitations of the probate inventory', in Joan Chartres and David Hey (eds), English Rural Society, 1500-1800: Essays in Honour of Joan Thirsk (Cambridge: Cambridge University press, 1990), pp. 139-74.

Stevenson, Christine, The City and the King: Architecture and Politics in Restoration London (New Haven, CT: Yale University Press, 2013).

Thrupp, Sylvia L., The Merchant Class of Medieval London, 1300-1500 (Chicago, IL: University of Chicago Press, 1948).

Tittler, Robert, Architecture and Power: The Town Hall and the English Urban Community c. 1500-1640 (Oxford: Clarendon Press, 1991).

Tittler, Robert, 'Reformation, civic culture and collective memory in English provincial towns', Urban History, 24:3 (1997), 283-300.

Tittler, Robert, The Reformation and the Towns in England: Politics and Political Culture, c.1540-1640 (Oxford: Clarendon, 1998).

Tittler, Robert, The Face of the City: Civic Portraiture and Civic Identity in Early Modern England (Manchester: Manchester University Press, 2007).

Tittler, Robert, 'Portraiture, precedence and politics amongst the London liveries, c. 1540-1640', Urban History, 35:3 (2008), 349-62.

Unwin, George, The Gilds and Companies of London, 4th edn (London: Cass, 1963).

Walker, Matthew, Architects and Intellectual Culture in Post-Restoration England (Oxford: Oxford University Press, 2017).

Wallis, Patrick, 'Controlling commodities: search and reconciliation in the early modern livery companies', in Ian Anders Gadd and Patrick Wallis (eds), Guilds, Society and Economy in London 1450-1800 (London: Centre for Metropolitan History, Institute of Historical Research in association with Guildhall Library, 2002), pp. 85-100.

Wallis, Patrick, 'Apprenticeship and training in premodern England', The Journal of Economic History, 68:3 (2008), 832-61.

Wallis, Patrick and Wright, Catherine, 'Evidence, artisan experience, and authority in early modern England', in Pamela H. Smith, Amy R. W. Meyers, and Harold 
J. Cook (eds), Ways of Making and Knowing: The Material Culture of Empirical Knowledge (Ann Arbor: The University of Michigan Press, 2014), pp. 138-63. Ward, Joseph, Metropolitan Communities: Trade Guilds, Identity, and Change in Early Modern London (Stanford, CA: Stanford University Press, 1997).

Welch, Charles, History of the Worshipful Company of Pewterers: Based Upon Their Own Records, 2 vols (London: Blades, East \& Blades, 1902).

Welch, Charles, History of the Cutlers' Company of London and of Minor Cutlery Crafts, 2 vols (London: Privately printed for the Cutlers' Company, 1916-22).

White, Adam, 'A biographical dictionary of London tomb sculptors c. 1560-c. 1660', The Volume of the Walpole Society, 61 (1999), pp. 1-162.

Whittle, Jane, 'A critique of approaches to "domestic work": women, work and the pre-industrial economy', Past and Present, 243:1 (2019), 35-70.

Withington, Phil, 'Two renaissances: urban political culture in post-Reformation England reconsidered', Historical Journal, 44:1 (2001), 239-67.

Withington, Phil, The Politics of Commonwealth: Citizens and Freemen in Early Modern England (Cambridge: Cambridge University Press, 2005).

Withington, Phil, 'Company and sociability in early modern England', Social History, 32:3 (2007), pp. 291-307.

Withington, Phil, Society in Early Modern England: The Vernacular Origins of Some Powerful Ideas (Cambridge: Polity, 2010).

Wood, Andy, The Memory of the People: Custom and Popular Senses of the Past in Early Modern England (Cambridge: Cambridge University Press, 2013).

Wrightson, Keith, English Society, 1580-1680 (London: Routledge, 2003).

Zilsel, Edgar, 'The sociological roots of science', The American Journal of Sociology, $47: 4$ (1942), 544-62. 